\title{
Assessing the effectiveness of a 'site visit' on recruitment rates in a multicentre randomised trial: SWAT-1
}

\author{
Valerie Smith ${ }^{1,3^{*}}$, Mike Clarke ${ }^{2}$, Cecily Begley ${ }^{1}$, Declan Devane ${ }^{3}$ \\ From 3rd International Clinical Trials Methodology Conference \\ Glasgow, UK. 16-17 November 2015
}

\section{Background}

The SWAT (Studies within a Trial) programme, established by the All-Ireland Hub for Trials Methodology Research in collaboration with the Medical Research Council Network of Hubs in the UK and others, is developing methods to resolve uncertainties about trial conduct through embedded research. SWAT-1 provides an initial example.

\section{Aim}

To evaluate the effects of a site visit on recruitment rates in a multi-centre randomised trial.

\section{Methods}

Using the SWAT-1 design, a before-and-after comparison used the date of the site visit as the time point for the intervention. Site A received the site visit. Sites B and C did not receive it and acted as the controls. The primary outcomes were the difference in recruitment in each site from 1 and 3 months pre-intervention to 1 and 3 months post-intervention.

\section{Results}

Recruitment rates increased in Site A post-intervention (17\% and $14 \%$ percentage point increases at 1 and 3 months, respectively). No differences in recruitment occurred in Site B or in Site C. At 3 months post-intervention, a significant difference was detected in favour of higher recruitment in A compared to $\mathrm{B}+\mathrm{C}$ ( $34 \%$ versus $25 \%$; odds ratio $1.57,95 \%$ confidence interval 1.09-2.26). These findings suggest that recruitment might increase

${ }^{1}$ Trinity College Dublin, Dublin, Ireland

Full list of author information is available at the end of the article from 2 participants per week before the site visit to 4-5 per week after it.

\section{Conclusion}

This initial example of a SWAT provides evidence that a site visit increases recruitment rates in a trial. Further SWAT-1s are required to substantiate these findings and to examine the effects in different trials in different settings.

\section{Authors' details}

${ }^{1}$ Trinity College Dublin, Dublin, Ireland. ${ }^{2}$ Queen's University, Belfast, UK.

${ }^{3}$ National University of Ireland, Galway, Ireland.

Published: 16 November 2015

doi:10.1186/1745-6215-16-S2-O10

Cite this article as: Smith et al:: Assessing the effectiveness of a 'site visit' on recruitment rates in a multicentre randomised trial: SWAT-1. Trials 2015 16(Suppl 2):010.
Submit your next manuscript to BioMed Central and take full advantage of:

- Convenient online submission

- Thorough peer review

- No space constraints or color figure charges

- Immediate publication on acceptance

- Inclusion in PubMed, CAS, Scopus and Google Scholar

- Research which is freely available for redistribution
() Biomed Central 